\title{
POLICIES TO PROMOTE CORPORATE SOCIAL RESPONSIBILITY (CSR) AND ASSESSMENT OF CSR IMPACTS
}

\author{
Jintao Lu, Licheng Ren, Wenfang Lin, Yifan He, Justas Streimikis
}

\section{Introduction}

When implementing sustainable development principles, business should play the core role, and the corporate social responsibility is one of the examples of the active role of enterprises in implementing sustainable development goals. The corporate social responsibility (CSR) describes the companies that are aware of their mission and take responsibility for their impact on society in general. The CSR is vital for sustainability, competitiveness, advance of companies and development of the world economy. The CSR provides benefits for risk controlling, allows cost savings and stipulates affordability of the capital, facilitates stakeholders' relationships and improvement of human resource management. In practice, human rights and corporate social responsibility have become an important aspect of business strategies for many companies.

The corporate social responsibility is central to the sustainability, competitiveness and innovation of the economy of each country and is tightly linked to the success when implementing Sustainable Development Goals (SDGs) by world countries. The importance of CSR has increased in recent years, taking into account the vivid growth of institution, funds, various online platforms and portals that are dealing with the CSR and inspiring enterprises to Improve their practices, according to various responsibility practices and criteria (Guenster et al., 2010; Ghoul et al., 2011). Overall, the CSR definition covers quite different kinds of socially responsible behaviours. All these responsible behaviours can be allocated to three areas: environmental, social and governance (ESG) factors.

The Environmental dimension covers obligations to integrate environmental considerations into all the activities of companies, for example, the designing, manufacturing, supplying and distributing of products.
The Social dimension is associated with positive human resources management, taking into account human rights requirements and includes appropriate training, career development, employee participation, quality of working condition standards.

The Governance dimension is linked to the companies' relationship and interaction with various shareholders such as customers and suppliers, regulation bodies, strategic alliances etc. The main behavioural practices include the prevention of interest conflicts, corruption, fair information supply to consumers etc.

There is a dramatic growth of organizations that are focused on the national and international levels by providing advice and implementing various projects and programs around the world. There are hundreds of CSR that are reporting initiatives and tools all over the world. There are various public policies to promote the CSR that are implemented in different countries. These trends of dramatic growth of the CSR activities indicate that literature on the CSR have already shifted from the issues, which are relevant to the companies' mission and value of the CSR to the firm, to the processes by which companies enact their societal impacts by implementing CSR and to the societal outcomes of this. Therefore, nowadays, the main issue is how societies and countries can benefit from the CSR, especially in terms of dealing with major sustainable development challenges, such as poverty, education, health, energy and environment. Recent scientific discussion on the assessment of impacts of the CSR and measures to promote the CSR provides contradictory results and findings.

Therefore, the aim of this paper is to analyse and categorize public policies and measures to promote the CSR and assess the CSR impacts. In order to achieve this aim, the following tasks have been set: 
1. To analyse and systematize recent literature on the CSR;

2. To discuss the main policies and measures and reporting initiatives to promote CSR and their dynamics;

3. To analyse measures for the assessment of CSR impacts;

4. To analyse the CSR impact on Sustainable Development Goals;

5. To provide policy recommendations based on the conducted analysis.

The structure of the paper: in the first section of paper, the literature review on the CSR and its impacts is provided; in the second section, the main policy tools, aiming at the promotion of CSR and reporting requirements, are systematized; in the third section, the measures to assess the impacts of CSR critically is analysed; in the fourth section, the questions of linking CSR impact with sustainable development goals are developed, and the impact of CSR on SDGs is analysed; in the fifth section, the conclusions and policy implications are provided.

\section{Literature Review}

Recently, there have been published numerous papers that are still dealing with the CSR concept. Numerous definitions of CSR were developed; however, no clear definition has been provided, making the measurement of CSR and its difficult impacts (Kotler \& Lee, 2005; Caroll, 2008; Turker, 2009; Aguinis \& Glavas, 2012; Eccles et al., 2012; Lee \& Krisnawati, 2014; Maxfield, 2015). The CSR activities in literature cover the integration of social issues into the design of products and manufacturing processes, adopting proactive human resource management tools and mechanisms, advancing the goals of community and NGO developments, ensuring better standards of environmental protection by implementing pollution abatement and the recycling of waste etc.

Similarly, there is still not declining interest among scholars in the precursors and the results of CSR; however, for both academicians and policy makers, the analysis of CSR is still quite chaotic, and there are no commonly agreed theoretical assessment frameworks and measurement techniques for the CSR impacts. The empirical methods are lacking theoretical framework and have not been agreed among scholars and practitioners. In addition, it is difficult to analyse the SCR antecedents and consequences of the CSR by applying one single discipline.

Most of the papers that are analysing the consequences of CSR focus on the relation between CSR and firm performance. These studies examined mainly the changes in stock prices for short-run and used them as a proxy for the assessment of companies' performance. Some studies applied regression analysis for assessing the profitability based on the return on assets. They applied the return on assets as a dependent variable in the regression model and tried to answer the question whether firms do well by doing good. The results of these studies showed contradictory findings: negative relation between the CSR and return on assets or no relation at all. Some studies found a positive relationship between CSR and the firms' profits (Lenz et al., 2017; Price \& Sun, 2017; Varadarajan \& Kaul, 2017; Armstrong \& Green, 2013; Lee \& Maxfield, 2015; Mayer, 2015).

There is no consistency in the results of these studies, dealing with the impacts of CSR on firms' performance. This is due to various inconsistencies linked to the definition of CSR, definition of firm performance and indicators of this performance, variances of samples, research design, changes over the time, which were not properly taken into account (Chernev et al., 2015; Aspelund, 2017).

Therefore, the empirical research dealing with the impact of CSR on firms' performance is confusing and not conclusive at all. According to Wang et al. (2016), this is linked to the application of different CSR meanings, not theoretically soundly defined measures of the CSR and wide differences in the research methodologies.

McWilliams and Siegel (2000) emphasized the weaknesses of the event study methodology to assess the consequences of the CSR that are applied in most studies. McWilliams and Siegel (2000) proved in their paper that the results of all event studies on the CSR that were published in top management journals were unreliable and had very serious flaws in both research design and implementation. Moreover, they questioned the application of conventional regression for the analysis of the relationship between corporate social responsibility and firm performance.

Baron (2001) made a distinction between altruistic CSR and strategic CSR, and Hillman 
and Keim (2001) proved that empirical tests of the relation between CSR and firm performance should disaggregate CSR activities based on this principle. The strategic CSR is addressed by the stakeholder management, and the altruistic CSR is targeting social issues. Hillman and Keim (2001) applied disaggregated model and reported that there is a positive relationship between the firm economic performance and strategic CSR, and there is a negative relationship between the altruistic CSR and the firm's economic performance.

Though, in literature, there has been made many attempts to define the determinants of CSR, it is still unclear what is the main reason for companies to employ or not employ the CSR disclosure practices even now (Crilly et al., 2016; Servaes \& Tamayo, 2013; Epstein, Buhovac, 2016). There is a considerable increase in literature on the CSR disclosure; however, only a limited number of papers are dealing with the relationship between the CSR penetration and institutional factors that have an impact on the CSR disclosure (Desai, 2016; Collucia et al., 2018).

According to Campbell (2007), the responsible behaviour of companies is affected by such institutional factors as follows: cultural traits, regulations, the presence of institutionalized norms on the CSR disclosure, corruption perception level etc. These institutional drivers have a systematic effect on the CSR behaviour of firms. Some studies proved that CSR penetration is higher in countries that have weaker institutions. Jackson and Apostolakou (2010) have investigated the impact of different institutional factors on the CSR policies of the selected European firms and showed that firms that are operating in Anglo-Saxon countries (liberal market economies) have a higher level of CSR penetration and disclosure than firms in the other European countries that are having more regulated economies like the Mediterranean or Continental countries. The study (Jackson \& Apostolakou, 2010) revealed that firms in countries with stronger institutions are able to reach just the minimum standard of CSR without seeking for the best or highest results. Another study by El Ghoul et al. (2017) showed that the CSR disclosure value is greater in countries with weaker institutions and more laissez-faire governments. However, other studies found a positive relationship between the strong institutions and CSR penetration (Dhaliwal et al., 2012). Ioannou and Serafeim (2012) proved that the cultural traits, political system in the country and education system have the most significant impact on the CSR disclosure. Cahan et al. (2016) examined the impact of quality of institutions on the CSR disclosure level and showed that all these factors have a positive and strong impact on the CSR penetration and performance. It could be concluded that the higher is the quality of institutions in the country, the higher is the penetration of the CSR. GarciaSanchez et al. (2016) examined the CSR performance of firms in 20 developed countries and showed that companies in countries with strong institutional environment make all efforts to ensure their CSR disclosure. In addition, the firms that are operating in countries with higher long-term orientation, collectivism, feminism and uncertainty avoidance are more keen on the CSR disclosure. The study by Colucia et al. (2018) proved that a strong legal system in the country has a positive impact on the CSR performance and disclosure. Therefore, the main conclusion is that social, political and legal factors have an impact on the transparency of corporate behaviour of companies. The following institutional factors that are the most important for the level of CSR disclosure, i.e., regulatory quality, rule of law and voice and accountability, have a positive impact on the CSR disclosure. Such factors as political stability and governance effectiveness have insignificant impact on the CSR penetration (Colucia et al., 2018).

Therefore, the literature on CSR can be broadly divided into three groups, based on the content of studies: (1) antecedent, (2) outcome and (3) process oriented. The "antecedent" category studies analyse the main factors that determine firm's engagement in the CSR. The policies and measures and reporting initiatives can be treated as the driving forces of CSR. The literature of "outcome" category examines the consequences of CSR. These studies are addressing the assessment of CSR impacts. The third group of studies analyse the "process" of CSR decision making or implementation and how various stakeholders respond to the corporate social activities (Wang et al., 2016). This group of literature tries to find the linkages between the effectiveness of policies and reporting initiatives and stakeholders' engagement and help to pursue sustainable development goals by responsible companies. 
There is a clear trend of conceptual shift of the articles in the "outcome" group from financial outcomes to non-financial, social and organizational outcomes. Scholars tend to be more interested in a broader construal of the role of businesses and corporations in the society as well as providing the mechanisms (likely mediating factors), through which he CSR is linked to the financial performance.

\section{Policies and Reporting Initiatives to Promote the CSR}

Today, Europe is regarded as a leader in the CSR and CSR policies. Governments are trying to promote CSR policies because CSR practices can help to meet the sustainable development policy objectives of the country on a voluntary basis. This motivation is linked to the policy objectives that are related to sustainable development goals and environmental protection as well as to foreign policy such as development assistance and aid. Therefore, most governments in the European Union (EU) have an increasingly active role in promoting CSR activities. The policies to promote CSR can be grouped into four main areas:

1. Raising awareness of companies and general public about the CSR and building firms' capacities to implement CSR;

2. Improving the disclosure and transparency of companies CSR;

3. Fostering the Socially Responsible Investment (SRI);

4. Leading in the CSR activities by providing example such as public procurement or applying SRI in governmental funds, applying CSR in public companies etc.

All public policies to promote the CSR can be grouped into 4 clusters:

- Legal instruments that are prescribing the desired choices and actions by making use of the state's legislative powers such as laws, directives and regulations;

- Economic instruments that provide initiatives to influence behaviour with financial and market measures, such as awards, taxes, tax allowances and subsidies;

- Informational instruments are based on persuasion by providing relevant information, for example, education, training information campaigns and website platforms;

- Networking instruments that are based on the networking of stakeholders, assuming that different stakeholders are interested in joined efforts to achieve the shared objectives, like stakeholder forums, negotiated voluntary agreements and public-private partnerships etc.

Public policies and measures to promote the CSR and a number of initiatives in the group of the EU countries are provided in Tab. 1.

The European Union Member States and associated countries can be allocated into 5 groups based on their geographical and cultural traits and their welfare models: Scandinavian (Norway, Sweden, Finland, Iceland), Anglo-Saxon (The UK, Ireland), Mediterranean (Spain, Italy, Portugal, Greece, Malta, Cyprus), Continental (Germany, Austria, Belgium, Switzerland, France, Luxemburg) and Transitional (Lithuania, Latvia, Estonia, Bulgaria, Romania, Hungary, Slovenia, Slovakia, The Czech Republic) (Steurer et al., 2012). The number of policy instruments to promote CSR is provided for the group of countries. As one can notice from Tab. 1, Anglo-Saxon countries and Scandinavian countries are leaders in the public policies that are targeting CSR.

In many EU member states, the voluntary efforts by firms to measure and report on CSR or sustainability performance were followed by various numbers of mandatory disclosure requirements, which are implemented by the governmental regulation. This is especially the case of the EU countries, where new reporting requirements have been introduced by the legal acts laws such as firms' laws, accounting laws and other instruments that address the reporting requirements and CSR disclosure requirements.

Currently, there are almost 400 sustainability reporting instruments that are implemented all around the world. These reporting initiatives can be treated as instruments to promote CSR. The study (KPMG, 2016) found over 400 instruments in 64 world countries. These trends indicate the increasing commitments of countries and firms to promote high transparency and sound accountability. However, a large number of different CSR disclosure instruments make a big problem for reporting companies and governments. The harmonization of CSR reporting instruments is a major goal of the international institutions, policy makers and regulators, stock exchange operators, industrial union and associations, 
Tab. 1: Public policies to promote CSR

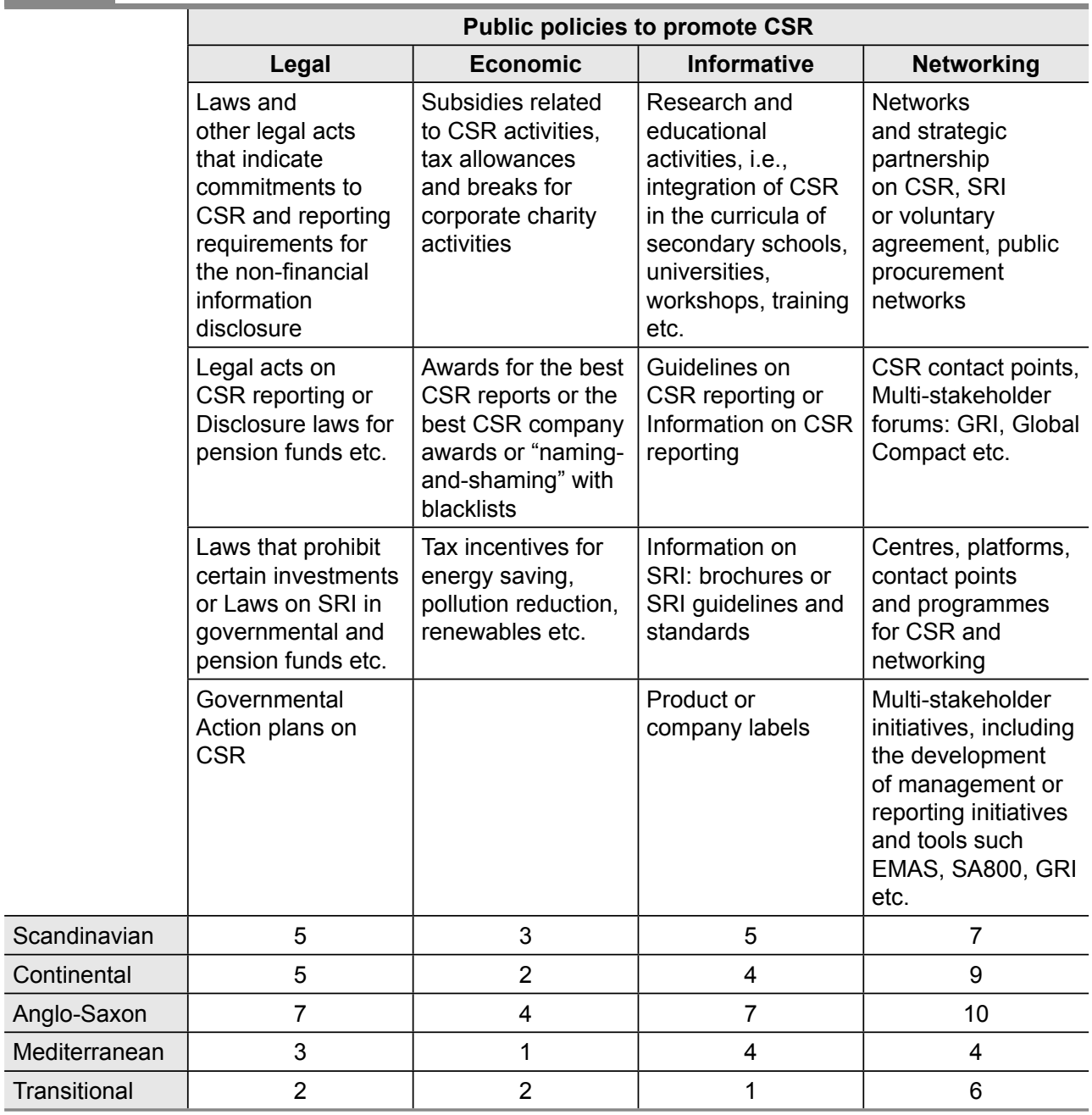

Source: authors' own compilation based on Steurer (2010), Steurer et al. (2012), Pimentel et al. (2016), Halkos and Skouloudis (2016), Albareda (2007)

standard setting authorities and scholars that are engaged in development and creation of advanced reporting tools. In 2013, 180 CSR reporting instruments were identified in 44 world countries (KPMG, 2013). There is the dramatic growth of the CSR reporting instruments in Europe, Asia Pacific and Latin America. Tab. 2 presents the trends in CSR reporting around the world.

State regulators increasingly encourage firms to disclose information that is linked to the
CSR practices in their annual reports. Around $70 \%$ of the total CSR reporting instruments in 2016 were mandatory. Around $30 \%$ of the CSR reporting instruments were voluntary (KPMG, 2016).

In most countries, CSR reporting instruments are focused mainly on large companies and state-owned enterprises. The largest companies in the stock exchange and companies operating in high-impact sectors are required to disclose non-financial information, 
Tab. 2: Trends in the CSR reporting and disclosure

\begin{tabular}{l|l|l|l|l|l|l|l|l|l} 
& & \multicolumn{2}{|c|}{$\mathbf{2 0 0 6}$} & \multicolumn{2}{|c|}{$\mathbf{2 0 1 0}$} & \multicolumn{2}{|c|}{$\mathbf{2 0 1 3}$} & \multicolumn{2}{|c}{$\mathbf{2 0 1 6}$} \\
\hline $\begin{array}{l}\text { CSR reporting } \\
\text { Instruments }\end{array}$ & $\begin{array}{l}\text { Mandatory CSR } \\
\text { reporting instruments }\end{array}$ & 35 & $58 \%$ & 94 & $62 \%$ & 130 & $72 \%$ & 248 & $65 \%$ \\
\cline { 2 - 9 } & $\begin{array}{l}\text { Voluntary CSR } \\
\text { reporting instruments }\end{array}$ & 25 & $42 \%$ & 57 & $38 \%$ & 50 & $28 \%$ & 135 & $35 \%$ \\
\cline { 2 - 9 } & $\begin{array}{l}\text { Total CSR reporting } \\
\text { instruments }\end{array}$ & \multicolumn{2}{|c|}{60} & \multicolumn{2}{|c|}{151} & 180 & \multicolumn{2}{|c}{383} \\
\hline Countries & \multicolumn{2}{|c|}{19} & \multicolumn{2}{|c|}{32} & 44 & \multicolumn{2}{|c}{71} \\
\hline
\end{tabular}

Source: KPMG $(2016 ; 2013)$

as these firms have financial and human resources for such reporting practices, while smaller companies do not have the capacity to report.

The main policy instruments that are requiring sustainability reporting are governmental regulation, codes of conduct, various informative and some economic measures, standards and other public policies such as government action plans, strategies and national schemes. Moreover, firms are required to demonstrate responsible tax strategies and ensure the payment of taxes. A sustainability rating such as the Dow Jones Sustainability Index is driving the responsible taxation policies into the evaluation criteria for the SRI as well.

Over 60 percent of the instruments that were identified in 2016 cover the reporting on specific environmental or social topics. The remaining instruments encourage the reporting on general sustainability information. The number of instruments on social information disclosure almost doubled since 2013. Around half of the reporting instruments on social issues are in the EU. Several EU member states in response to the EU's CSR Strategy have implemented national action plans to address the CSR, for example, Spain has adopted the Strategy for Corporate Social Responsibility 2014-2020. Other countries have developed national CSR action plans (France, Switzerland, Norway).

The EU has introduced mandatory requirements for reporting on specific environmental or social issues as well as on wide non-financial performance indicators (policies, risks and outcomes that are related to environment, social issues, respect for human rights, anti-corruption issues, diversity etc.).
Therefore, the number of reporting instruments has continued to grow significantly since 2013 in the EU, as in 2016, 155 instruments were identified compared to 80 in 2013. Some of them are linked to the transposition of the EU Non-Financial Reporting Directive. New EU reporting instruments were linked to the GHG emissions trading.

There are many CSR reporting instruments and CSR disclosure initiatives; however, it is important to assess the impact, context and drivers behind each instrument and answer the question how effective are these instruments and to what extent does the CSR reporting initiatives bring the world nearer to the sustainable world, projected by the 2030 Agenda for Sustainable Development.

\section{Assessment of CSR Impacts}

There are several studies that are dealing with the assessment of CSR impacts (Gjølberg, 2009; Hamer, 2005; Foote, Gaffney, \& Evans, 2010; Jankalova, 2013; Jankalova, 2016). The main CSR assessment approaches are generalized in Tab. 3 .

As one can see from Tab. 3, some CSR assessment tools are constructed for reporting purposes, some are more linked with the assessment of companies' activities, and some are constructed for the self-assessment of companies. There are tools that can be used for all these purposes, as SA8000 or EMAS.

There are business excellence models as well that are often applied as frameworks for the assessment of CSR practices in firms. The most popular and well-known models are the EFQM Excellence Model that was elaborated in Europe and The Malcolm Baldrige Model for Performance Excellence that was developed 


\begin{tabular}{|c|c|c|c|}
\hline $\begin{array}{l}\text { CSR Assessment Approach } \\
\text { or Instrument }\end{array}$ & $\begin{array}{l}\text { Tool } \\
\text { for reporting }\end{array}$ & $\begin{array}{c}\text { Tool } \\
\text { for self- } \\
\text { assessment }\end{array}$ & $\begin{array}{c}\text { Tool } \\
\text { for assessment } \\
\text { of companies' } \\
\text { activities }\end{array}$ \\
\hline World's Most Ethical Companies & & & + \\
\hline Global 100 Most Sustainable Corporations & & & + \\
\hline OHSAS 18001 & + & + & + \\
\hline Social Accountability - SA 8000 & + & + & + \\
\hline ISO 14000 & + & + & + \\
\hline EMAS & + & + & + \\
\hline KPMG Survey & & & + \\
\hline GHG Protocol & + & + & + \\
\hline Carbon Disclosure Project (CDP) & + & + & + \\
\hline Global Reporting Initiative (GRI) & + & + & \\
\hline $\begin{array}{l}\text { World Sustainable Development Council } \\
\text { for Business }\end{array}$ & + & + & \\
\hline Dow Jones Sustainability Index & & + & \\
\hline FTSE4good Index & & + & + \\
\hline The ECPI Global ESG Alpha Equity Index & & + & + \\
\hline MSCI World ESG Index & & + & + \\
\hline ECPI Global ESG Alpha Equity Index & & + & + \\
\hline
\end{tabular}

in the USA. Jankalová and Radoslav (2017) have systematized the CSR assessment tools and methods and found that the Malcolm Baldrige Model for Performance Excellence is more suitable for the assessment of CSR in the firm as the EFQM Excellence Model (Foote, Gaffney, \& Evans, 2010).

The independent agencies (Dow Jones from Switzerland, FTSE from the UK, Global 100 in the US etc.) deal with the rating of the CSR of firms. They have created their own indexes to measure the CSR performance of firms (Hammer, 2005). A decision to include firms in the index calculation depends on the firms' fulfilment of specific criteria that is set by the independent agencies. The most popular and well-known international indexes are Dow Jones Sustainability Index, FTSE4Good Index, Ethibel Index and MSCI World ESG Index.

The Dow Jones Sustainability World Enlarged Index (DJSI World Enlarged) assesses the performance of the top $20 \%$ of the world largest 2,500 firms in the S\&P Global Broad Market Index in terms of CSR. It is one of the most important world indices for socially responsible investing (SRI).

The FTSE4Good Global Index was developed by the FTSE International and Ethical Research Services (EIRIS). The aim of the index is to assess the performance of firms around the world that meet globally recognised CSR standards. It is as well among the most important indexes for socially responsible investing.

The Ethibel Sustainability Index (ESI) Excellence Global collects the best-in-class firms in relation to the CSR across various sectors and regions in Europe, North America and Asia Pacific. It is constructed as a freefloat weighted index that is combining the CSR assessment values with the sector weights on the S\&P Global 1200. 
MSCl World ESG Index consists of large and mid-cap firms and provides the assessment of firms, according to high environmental, social and governance performance criteria that is relative to their sector peers.

The World's Most Ethical (WME) companies' designation was created by the Ethisphere Institute. It covers the world firms by promoting ethical standards and shaping the future industry standards. The assessment and selection procedures of firms are based on the proprietary rating system.

The Global 100 assesses the Most Sustainable Corporations in the World. This sustainability equity index is developed by the Corporate Knights advisory group.

KPMG'S International Survey of Corporate Responsibility Reporting is an analysis of corporate nonfinancial reporting of firms and includes the assessment of CSR disclosure practices among the 100 largest firms in the selected countries.

The main aim of the sustainability indexes is to measure the performance of companies that meet certain CSR criteria and provide investors with SRI opportunities. These indexes have a positive impact on the socially and environmentally responsible investments all around the world. Some independent institutions that are issuing indexes as well want to increase the awareness about the CSR and SRI and promote socially and environmentally responsible behaviour. However, there is a big problem with these indexes due to the lack of the objectivity (Jankalova, 2016). The collected data cannot be reliable as it comes from personal interviews, websites, annual reports etc. Despite the verification by the independent institution, these reports are subjective and lack transparency. The independent rating agencies apply their own not disclosed methodology because it is their expertise, and they have invested big resources in its creation. The major problem with indexes is that they are different in the analysed and applied indicators for the applied CSR assessment and scales, and it is very difficult to compare these indexes. The incomparability of indexes as well causes the variety of definitions of CSR (Jankalova, 2016).

For the CSR reporting of firms, the most important are these standards: Global Reporting Initiative, World Business for Sustainable
Development Reporting Project, UN Global Compact, ISO 14001, SA 8000 , OHSAS 18001, Carbon Disclosure Project, GHG protocol etc.

The GRI Sustainability Reporting Guidelines are the most widely used CSR and sustainability reporting framework in the world, which allow private firms and public organizations to report on their CSR performance, based on the economic, environmental, social and governance criteria. The GRI Guidelines present a set of important issues and principles, standard disclosures and implementation manuals for developing the CSR reports.

The World Business Council for Sustainable Development (WBCSD) is a global association of firms that is seeking to promote strategic issues linked to the CSR and sustainability. It presents a well-developed platform for companies to network, share best practices and problematic issues.

The Global Compact was developed by the United Nations as a strategic initiative for firms to implement the ten universally accepted principles on human rights protection, labour standards, environmental protection and transparency.

Carbon Disclosure Project (CDP) is an international organization that is cooperating with the market forces in order to encourage companies to measure, manage and disclose important environmental information that is linked to the GHG (greenhouse gas) emissions and take action to mitigate climate change.

The GHG Protocol is an accounting tool for the assessment of GHG emissions by encouraging contribution to mitigate climate change. It presents the GHG emission accounting framework for various programs around the world.

ISO 14001 is an environmental management system standard that has been developed by the International Organization for Standardization (ISO). It presents a framework for a private company or public organization in setting up an environmental management system and monitoring its performance.

The SA 8000 standard is an auditable certification standard. It imposes requirements for human rights protection, implementation of socially acceptable practices in the workplace for workers and their families. SA 8000 was developed by the Social Accountability International (SAI) by applying the same approach as for ISO 14001. 


\section{Business Administration and Management}

OHSAS 18001 is an occupational health and safety management system standard that has been developed by the Occupational Health and Safety Advisory Services (OHSAS) Project Group. The standard aims to help organizations to manage the occupational health and safety.

As there are many various CSR assessment tools, it is very difficult to assess the number of socially responsible companies in specific countries or all over the world, and this is an important problem for defining CSR penetration and assessing the impact of public policies by aiming at the promotion of CSR.

There were several attempts to develop a multidimensional CSR index to improve the knowledge of global CSR trends and developments (Gjolberg, 2009; Halkos \& Skouloudis, 2016). Gjolberg's index was based on nine international CSR variables that are linked to socially responsible investment ratings, subscriptions to global CSR initiatives, CSR accounting and reporting schemes and environmental or social management system standards (Halkos \& Skouloudis, 2016). Recently, a CSR index that has been developed by Gjolberg in 2009 was used and extended by Halkos and Skouloudis (2016) in order to obtain national CSR scores. While Gjolberg (2009) had applied the calculation formula to 20 OECD countries, Halkos and Skouloudis assessed the data relating to 86 countries, selecting the year 2012 as the reference period and as variables using 16 international CSR initiatives, environmental and social standards, CSR rankings and ethical investment stock exchange indices. The variables that were included in Halkos and Skoloudis (2016) CSR index are presented in Tab. 5 where countries are ranked in terms of CSR penetration based on the CSR index.

\begin{tabular}{|c|c|c|c|c|c|c|c|}
\hline \multirow{2}{*}{$\begin{array}{l}\text { Tab. 4: } \\
\text { CSR } \\
\text { Rating }\end{array}$} & \multicolumn{7}{|c|}{$\begin{array}{l}\text { Rankings of top } 20 \text { countries based on the CSR index and number } \\
\text { of CSR enterprises in } 2017\end{array}$} \\
\hline & Country & GRI & ISO 14000 & $\begin{array}{l}\text { Global } \\
\text { Compact }\end{array}$ & SA 8000 & WBCSDE & CSR Index \\
\hline 1 & Switzerland & 110 & 2,856 & 153 & 5 & 9 & 20.64 \\
\hline 2 & Sweden & 196 & 9,486 & 296 & 1 & 2 & 19.50 \\
\hline 3 & Finland & 162 & 1,480 & 79 & 1 & 5 & 18.99 \\
\hline 4 & Denmark & 66 & 1,128 & 370 & 4 & 4 & 12.59 \\
\hline 5 & The UK & 283 & 17,559 & 473 & 1 & 7 & 9.64 \\
\hline 6 & The Netherlands & 216 & 2,739 & 144 & 4 & 10 & 9.27 \\
\hline 7 & Norway & 88 & 1,319 & 24 & 1 & 8 & 8.04 \\
\hline 8 & Australia & 87 & 3,938 & 151 & - & 6 & 6.17 \\
\hline 9 & Spain & 154 & 13,053 & 1,483 & 14 & 3 & 4.21 \\
\hline 10 & France & 177 & 6,318 & 78 & 2 & 9 & 2.58 \\
\hline 11 & Portugal & 17 & 5,555 & 63 & 33 & 4 & 2.30 \\
\hline 12 & Singapore & 56 & 1,254 & 81 & - & - & 0.77 \\
\hline 13 & Japan & 205 & 23,901 & 290 & 2 & 27 & -0.25 \\
\hline 14 & Canada & 128 & 1,172 & 78 & - & 5 & -0.76 \\
\hline 15 & Belgium & 135 & 1,063 & 86 & 2 & 1 & -1.22 \\
\hline 16 & Italy & 145 & 26,655 & 27 & 1,309 & 4 & -1.56 \\
\hline 17 & Germany & 329 & 12,176 & 480 & 11 & 11 & -3.93 \\
\hline 18 & Hong Kong & & 1,023 & & 4 & - & -5.40 \\
\hline 19 & Iceland & 2 & 90 & 24 & - & - & -5.70 \\
\hline 20 & The USA & 353 & 5,251 & 119 & 1 & 38 & -11.02 \\
\hline
\end{tabular}


The number of enterprises that are implementing the major CSR instruments for reporting, self-assessment and assessment of company's activities in terms of CSR (GRI, ISO 18000, SA 8000, WBSDE) in top ranked countries on the CSR penetration (CSR index) are presented in Tab. 4.

As one can see from Tab. 4, the 7 top rated countries based on the CSR index are in Europe and are followed by Australia. The US is in the $20^{\text {th }}$ position of TOP 20 world countries, having highest penetration of the CSR. Japan is in the $13^{\text {th }}$ position and Canada in the $14^{\text {th }}$ position. Fourteen countries in this list are European developed nations. The domination of the EU member states in this list can be linked to the abundance of public policies to promote CSR in this region.

However, this assessment of penetration of CSR in the world countries, even though it enables to cover various CSR responsibility and reporting practices (16), does not provide answers about the impact of the CSR on the social challenges. Nevertheless, it is obvious from the top 20 countries presented in Tab. 6 that all these countries are highly developed strong economies that are having significantly less social problems that are addressed by Agenda 2030. However, the impact of CSR should be assessed based on the progress in achieving SDGs. The recent initiatives of Global Compact and GRI indicated that this should be addressed as a priority issue.

\section{CSR Impacts on the Sustainable Development Goals and Reporting}

In 2015, the world leaders united to adopt the 2030 Agenda and its 17 Sustainable Development Goals. The challenge of sustainable business is to translate this universal and holistic framework into an ambitious action and innovative solutions. The UN Global Compact is the world major leading platform for the development, implementation and disclosure of the CSR practices. It was initiated in 2000. Now, it is one of the largest CSR initiatives around the world, including over 9,500 companies and 3,000 non-business organizations from 160 countries and over 70 local networks. For responsible business, the Ten Principles of Global Compact represent the fundamental values that they should embed in their business strategy and operations to guide their conduct, and the 17 Sustainable
Development Goals describe the destination towards which they aim, i.e., to work towards the time-bound, quantitative targets. By defining clear objectives and targets for global society to reach by 2030 , the Global Goals provide a unique opportunity for business and a source of inspiration to explore how to develop new business models, product and service innovations and solutions as well as to tackle the challenges outlined by the Goals. Taking the principles-based approach to the Global Goals by integrating the Ten Principles ensures that the attempts to make a positive contribution to the Global Goals are not undermined by negative impacts that business might have as the result of neglecting its responsibilities related to human rights, labour, environment and anti-corruption. In order to understand how a company can meaningfully contribute to sustainable development, it must understand its actual and potential, direct and indirect, negative and positive impacts across its entire value chain related to all Ten Principles and 17 Global Goals. By understanding and prioritizing its impacts and taking action to prevent, mitigate and remedy any negative impacts while investing in scaling positive impacts, a company ensures it is making a positive contribution to the Global Goals and sustainable development more broadly.

In 2017, for the first time, a section on the SDG implementation was included in the survey. The 2018 United Nations Global Compact Progress Report (UN, 2018) is an assessment of how businesses are adopting the Ten Principles of the Global Compact in their strategy and operations as well as the evaluation of their actions to deliver on the UN Sustainable Development Goals, commonly referred to as the "Global Goals". The findings in progress report are based on the Annual UN Global Compact Implementation Survey, first issued in 2008. The Survey is an anonymous online survey of UN Global Compact participants worldwide to take stock of environmental and social performance and identify the trends and developments that are related to corporate sustainability issues. All 9,500 companies that are participating in the UN Global Compact were invited to take the 2018 survey, which is available in multiple languages. The 2018 survey is generally representative of the UN Global Compact participant base, in terms of company size, region and year that a company 


\begin{tabular}{|c|c|c|}
\hline SDGs & $\begin{array}{c}\text { The share of companies } \\
\text { reporting on their positi- } \\
\text { ve impact on the imple- } \\
\text { mentation of SDGs, \% }\end{array}$ & $\begin{array}{l}\text { The share of compa- } \\
\text { nies reporting that their } \\
\text { products and services } \\
\text { contributed towards } \\
\text { the implementation } \\
\text { of SDGs, } \% \\
\end{array}$ \\
\hline Goal 1 No Poverty & 64 & 33 \\
\hline Goal 2 Zero Hunger & 53 & 28 \\
\hline Goal 3 Good Health and Well-Being & 83 & 64 \\
\hline Goal 4 Quality Education & 71 & 44 \\
\hline Goal 5 Gender Equality & 83 & 55 \\
\hline Goal 6 Clean Water and Sanitation & 69 & 39 \\
\hline Goal 7 Affordable and Clean Energy & 63 & 50 \\
\hline Goal 8 Decent Work and Economic Growth & 98 & 65 \\
\hline Goal 9 Industry, Innovation and Infrastructure & 79 & 62 \\
\hline Goal 10 Reduced Inequalities & 72 & 42 \\
\hline Goal 11 Sustainable Cities and Communities & 61 & 49 \\
\hline $\begin{array}{l}\text { Goal } 12 \text { Responsible Consumption } \\
\text { and Production }\end{array}$ & 76 & 61 \\
\hline Goal 13 Climate Action & 64 & 53 \\
\hline Goal 14 Life Below Water & 31 & 16 \\
\hline Goal 15 Life on Land & 42 & 26 \\
\hline Goal 16 Peace, Justice and Strong Institutions & 53 & 28 \\
\hline Goal 17 Partnerships for the Goals & 66 & 40 \\
\hline
\end{tabular}

joined the initiative. Tab. 5 presents the main findings of the survey (UN, 2018), providing the assessment of responsible companies on the implementation of SDGs.

As one can notice from Tab. 5, the companies reported that their activities had a positive impact on all the SDGs; however, the biggest impact was made for Goal 8: Decent Work and Economic Growth, Goal 3: Good Health and Well-Being and Goal 5: Gender Equality. More than $50 \%$ of the companies reported that their products have contributed to Goal 8: Decent Work and Economic Growth, Goal 3: Good Health and Well-Being, Goal 5: Gender Equality, Goal 12: Responsible Consumption and Production, Goal 13: Climate Action, Goal 9: Industry, Innovation and Infrastructure.

However, the results of the most recent Eurobarometer survey (2012) that were conducted in the EU 27 member states revealed quite negative public opinion about the impacts of firms on the societal challenges and the implementation of sustainable development goals of the country. Only more than half of the European citizens believe that companies have a positive influence on society, while more than 4 out of 10 believe that companies have a negative influence. There is, however, a wide diversity of views across the EU 27 countries: from $85 \%$ of respondents in Denmark who think the influence of companies on society is generally positive to $36 \%$ of those in Italy and Slovenia. Opinions have divided on the question whether companies pay more or less attention to their influence on society than they did 10 years ago: $40 \%$ of the Europeans say that they pay more attention, while $39 \%$ say that they pay less attention. 
Therefore, the assessment of the CSR impact on the societal challenges cannot be an evaluation based on the opinion of companies or citizens. First of all, it is necessary to integrate the SDG in the CSR assessment. However, the main problem is the availability of many CSR reporting instruments and initiatives around the world. The GRI and Global Compact monitoring frameworks have already adjusted to some extent by linking company's activities with their input in the approaching of SDGs. However, clearer and more consistent indicators' systems that are linking SDGs goals, targets and indicators with company level indicators are necessary. Some indicators such as GHG emission reduction, energy efficiency improvements, the share of renewables in the energy consumption etc. can be easily transferred on company level; however, some indicators, especially those dealing with hunger, poverty, education etc., require more consolidated efforts between the scientists and policy makers.

It is as well possible to compare the countries' rankings based on the CSR index that is showing the level of penetration of CSR in companies with SDG index, indicating the updated assessment of countries' distance to achieve the Sustainable Development Goals (SDGs) and provide a ranking of countries by the aggregate SDG Index of the overall performance. It incorporates the trend data, and new indicators have been added more accurately to cover the SDGs and associated targets with a special focus on "leave no one behind" for the countries.

\section{Tab. 6: Rankings of countries based on the SDG index and CSR index}

\begin{tabular}{|c|c|c|}
\hline Country & SDG index ranking & CSR index ranking \\
\hline Sweden & 1 & 2 \\
\hline Denmark & 2 & 4 \\
\hline Norway & 3 & 7 \\
\hline Finland & 4 & 3 \\
\hline Switzerland & 5 & 1 \\
\hline Germany & 6 & 17 \\
\hline Austria & 7 & 25 \\
\hline The Netherlands & 8 & 6 \\
\hline Iceland & 9 & 54 \\
\hline The UK & 10 & 5 \\
\hline France & 11 & 10 \\
\hline Belgium & 12 & 15 \\
\hline Canada & 13 & 14 \\
\hline Ireland & 14 & 19 \\
\hline The Czech Republic & 15 & 53 \\
\hline The US & 25 & 20 \\
\hline Italy & 35 & 16 \\
\hline Russia & 47 & 77 \\
\hline Brazil & 52 & - \\
\hline China & 76 & 56 \\
\hline South Africa & 110 & 26 \\
\hline India & 110 & 36 \\
\hline
\end{tabular}

Source: authors' own compilation based on Halkos and Skouloudis (2016), Bertelsmann Stiftung and Sustainable Development Solutions Network (2018) 
The ranking of countries that is based on the CSR index and SDG index is provided in Tab. 6

As one can notice from the information presented in Tab. 6, the top 4 countries, according to the SDG index, are Scandinavian countries that are followed by Switzerland that has a high penetration of the CSR in their countries based on the CSR index. Moreover, these countries are among the leaders in developing and implementing public policies when targeting CSR. However, Iceland, having a very high ranking on SDG index, is ranked very low, according to the CSR index. The data for BRICS countries indicates that India and the Republic of South Africa that are having the highest rankings on the CSR index are ranked very poorly on the SDG index.

Though this simplified comparison between the rankings in CSR and SDG achievements does not provide a clear linking between the penetration of the CSR and the progress of countries towards the implementation of SDG; however, it emphasizes that the impact of CSR should be assessed based on the societal challenges such as Sustainable Development Goals.

\section{Conclusions and Policy Implications}

The majority of studies on CSR can be allocated to three groups: (1) antecedent, (2) outcome and (3) process oriented studies. The "antecedent" category studies analyse the main drivers of CSR, including policies and reporting initiatives. The "outcome" category studies deal with the consequences of CSR by addressing the CSR impacts on the company level. The "process" studies examine the CSR implementation process and try to find the linkages between the effectiveness of policies and the reporting initiatives and stakeholders' engagement to pursue the implementation of sustainable development goals on the company and society level.

The main conceptual shift of the articles in the "outcome" and "process" groups is from financial outcomes to non-financial, organizational and societal outcomes. The scholars are interested more in a broader construal of the role of businesses in a society as well as providing the mechanisms (likely mediating factors) through which the CSR can provide better results in pursuing sustainable development goals of the world countries.
The typology of governmental policies to promote the CSR can serve as a starting point for the assessment of the effectiveness of respective initiatives. The simplified assessment framework was applied by linking policies to promote the CSR and reporting initiatives with a number of socially responsible organizations and achievements of countries in terms of implementing the SDG goals.

The analysis revealed that public policies to promote the CSR can deliver positive results in implementing sustainable development goals of the country. The EU is a leader in policies promoting CSR and CSR reporting initiatives. The EU member states companies are very active in various CSR activities, such as EMAS, GRI, SA 8000, ISO 14001, Global Compact etc. The EU member states are as well the 12 top countries, based on the SDG Index in 2016. Three Scandinavian countries (Sweden, Denmark and Norway) are at the top of the SDG Index. This means that they are the closest now to achieving the SDG endpoints that are envisaged for 2030.

Because of the changes in the requirements of stakeholders, there is a constant demand for revision of sustainability indexes, standards and initiatives that are applied for the assessment of CSR activities of firms and the assessment of CSR impacts. Therefore, when dealing with this issue, it is important to monitor continuously the CSR impact on the society in general. For this purpose, the achievement of countries in implementing SDGs can be linked to the requirements of the CSR reporting.

The main problem is the availability of many CSR reporting instruments and initiatives around the world. The GRI and Global Compact monitoring frameworks have already been adjusted to some extend by linking company activities to their input in the approaching of SDGs.

However, clearer and more consistent indicators' systems that are linking the SDGs goals, targets and indicators with company level indicators are necessary. Some indicators as GHG emission reduction, energy efficiency improvements, the share of renewables in energy consumption etc. can be easily transferred to company level; however, some indicators, especially dealing with hunger, poverty, education etc., require more consolidated efforts between the scientists and policy makers. 
It is obvious that 2030 Agenda cannot be achieved by Governments or international institutions only. In order to address the needs of the most vulnerable people around the world, the dynamic role of business and new forms of sustainability financing are necessary. Sustainable business can contribute for the realization of Sustainable Development Goals by 2030 and deal with economic, environmental and social problems such as eradication of hunger and poverty through job creation, technological innovation and provision of financial resources and knowledge. In addition, responsible business brings a new approach to faster SDG implementation.

This work was supported by the Program for the Philosophy and Social Sciences Researchof Higher Learning Institutions of Shanxi (PSSR: 2017336) and the Doctoral Scientific Research Foundation of Taiyuan University of Science and Technology (No. W20182014).

\section{References}

Albareda, L. (2007). Public Policies on Corporate Social Responsibility: The Role of Governments in Europe. Journal of Business Ethics, 74(4), 391-407. https://doi.org/10.1007/ s10551-007-9514-1.

Armstrong, J. S., \& Green, K. C. (2013). Effects of Corporate Social Responsibility and Irresponsibility Policies. Journal of Business Research, 66, 1922-1927. https://dx.doi. org/10.1016/j.jbusres.2013.02.014.

Aspelund, A., Fjell, L., \& Rødland, S. E. (2017). Doing Good and Doing Well? International Entrepreneurship and Social Responsibility. International Journal of Entrepreneurship, 21(2), 13-32.

Aguinis, H., \& Glavas, A. (2012). What We Know and Don't Know about Corporate Social Responsibility: A Review and Research Agenda. Journal of Management, 38, 932-968. https://dx.doi.org/10.1177/0149206311436079.

Baron, D. (2001). Private Politics, Corporate Social Responsibility and Integrated Strategy. Journal of Economics and Management Strategy, 10(1), 7-45. https://doi.org/10.1111/ j.1430-9134.2001.00007.x.

Bertelsmann Stiftung and Sustainable Development Solutions Network. (2018). SDG Index and Dashboards Reports; A Global Report. New York, US. Retrieved from http:// sdgindex.org/reports/2018/.
Cahan, S. F., de Villiers, C., Jeter, D. C., Naiker, V., \& van Staden, C. J. (2016). Are CSR Disclosures Value Relevant? Cross-Country Evidence. European Accounting Review, 25(3), 579-611. https://doi.org/10.1080/09638180.201 5.1064009 .

Campbell, J. L. (2007). Why Would Corporations Behave in Socially Responsible Ways? An Institutional Theory of Corporate Social Responsibility. Academy of Management Review, 32(3), 946-967. https://doi.org/10.5465/ amr.2007.25275684.

Carroll, A. B. (2008). A History of Corporate Social Responsibility: Concepts and Practices. In A. Crane, A. McWilliams, D. Matten, J. Moon, \& D. Siegel (Eds.), The Oxford Handbook of Corporate Social Responsibility (pp. 19-46). Oxford: Oxford University Press.

Chernev, A., \& Blair, S. (2015). Doing Well by Doing Good: The Benevolent Halo of Corporate Social Responsibility. Journal of Consumer Research, 41(6), 1412-1425. https://doi.org/10.1086/680089.

Coluccia, D., Fontana, S., \& Solimene, S. (2018). Does Institutional Context Affect CSR Disclosure? A Study on Eurostoxx 50. Sustainability, 10(8), 2823. https://doi. org/10.3390/su10082823.

Crilly, D., Hansen, M., \& Zollo, M. (2016). The Grammar of Decoupling: Stakeholder Heterogeneity and Firm Decoupling of Sustainability Practices. Academy of Management Journal, 59, 705-729. https://doi.org/10.5465/ amj.2015.0171.

Desai, V. (2016). Under the Radar: Regulatory Collaborations and Their Selective Use to Facilitate Organizational Compliance. Academy of Management Journal, 59, 636-657. https://doi.org/10.5465/amj.2014.0943.

Dhaliwal, D. S., Radhakrishnan, S., Tsang, A., \& Yang, Y. G. (2012). Nonfinancial Disclosure and Analyst Forecast Accuracy: International Evidence on Corporate Social Responsibility Disclosure. Accounting Review, 87(3), 723-759. https://doi.org/10.2308/accr-10218.

Eccles, R. G., Perkins, K. M., \& Serafeim, G. (2012). How to Become a Sustainable Company. MIT Sloan Management Review, 53, 43-50.

Epstein, M. J., \& Buhovac, A. R. (2014). Making Sustainability Work: Best Practices in Managing and Measuring Corporate Social, Environment and Economic Impacts. Oakland, CA: Berrett-Koehler Publishers, Inc. 
El Ghoul, S., Guedhami, O., \& Kim, Y. (2017). Country-Level Institutions, Firm Value, and the Role of Corporate Social Responsibility Initiatives. Journal of International Business Studies, 48(3), 360-385. https://doi.org/10.1057/ jibs.2016.4.

García-Sánchez, I. M., CuadradoBallesteros, B., \& Frias-Aceituno, J. V. (2016). Impact of the Institutional Macro Context on the Voluntary Disclosure of CSR Information. Long Range Planning, 49(1), 15-35. https://doi. org/10.1016/j.Irp.2015.02.004.

Gjølberg, M. (2009). Measuring the Immeasurable? Constructing an Index of CSR Practices and CSR Performance in 20 Countries. Scandinavian Journal of Management, 25(1), 10-22. https://doi. org/10.1016/j.scaman.2008.10.003.

Halkos, G., \& Skouloudis, A. (2016). Cultural Dimensions and Corporate Social Responsibility: A Cross-Country Analysis [Munich Personal RePEc Archive (MPRA), Paper No. 69222]. https://mpra.ub.uni-muenchen.de/69222/1/ MPRA_paper_69222.pdf.

Hamner, B. (2005). Integrating MarketBased Sustainability Indicators and Performance Management Systems. Seattle, WA: Cleaner Production International.

Hategan, C.-D., Sirghi, N., Curea-Pitorac, R.-I., \& Hategan, V.-P. (2018). Doing Well or Doing Good: The Relationship between Corporate Social Responsibility and Profit in Romanian Companies. Sustainability, 10, 1041. https://doi.org/10.3390/su10041041.

Hillman, A., \& Keim, G. (2001). Shareholder Value, Stakeholder Management, and Social Issues: What's the Bottom Line? Strategic Management Journal, 22(2), 125-139. https://doi. org/10.1002/1097-0266(200101)22:2<125::AIDSMJ150>3.0.CO;2-H.

loannou, I., \& Serafeim, G. (2012). What Drives Corporate Social Performance? The Role of Nation-Level Institutions. Journal of International Business Studies, 43(9), 834-864. https://doi.org/10.1057/jibs.2012.26.

Jackson, G., \& Apostolakou, A. (2010). Corporate Social Responsibility in Western Europe: An Institutional Mirror or Substitute? Journal of Business Ethics, 94(3), 371-394. https://doi.org/10.1007/s10551-009-0269-8.

Jankalová, M. (2016). Approaches to the Evaluation of Corporate Social Responsibility. Procedia Economics and Finance, 39, 580-587. https://doi.org/10.1016/S2212-5671(16)30302-1.
Jankalová, M., \& Radoslav, J. (2017). The Assessment of Corporate Social Responsibility: Approaches Analysis. The International Journal Entrepreneurship and Sustainability Issues, 4(4), 441-459. https://doi.org/10.9770/ jesi.2017.4.4(4).

Kotler, P., \& Lee, N. (2005). Corporate Social Responsibility: Doing the Most Good for Your Company and Your Cause. Hoboken, NJ: Wiley.

Krisnawati, A., Yudoko, G., \& Bangun, Y. R. (2014). Development Path of Corporate Social Responsibility Theories. World Applied Sciences Journal 30 (Innovation Challenges in Multidiciplinary Research \& Practice), 110-120. https://doi.org/10.5829/idosi.wasj.2014.30.icmrp.17.

Lee, J., \& Maxfield, S. (2015). Doing Well by Reporting Good: Reporting Corporate Responsibility and Corporate Performance. Business and Society Review, 120, 577-606. https://doi.org/10.1111/basr.12075.

Lenz, I., Wetzel, H. A., \& Hammerschmidt, M. (2017). Can Doing Good Lead to Doing Poorly? Firm Value Implications of CSR in the Face of CSI. Journal of the Academy of Marketing Science, 45, 677-697. https://doi. org/10.1007/s11747-016-0510-9.

McWilliams, A., \& Siegel, D. (2000). Corporate Social Responsibility and Financial Performance: Correlation or Misspecification? Strategic Management Journal, 21(5), 603-609. https://doi.org/10.1002/(SICI)10970266(200005)21:5<603::AID-SMJ101>3.0.CO;2-3.

McWilliams, A., \& Siegel, D. (2001). Corporate Social Responsibility: A Theory of the Firm Perspective. Academy of Management Review, 26(1), 117-127. https://doi.org/10.2307/259398.

McWilliams, A., Siegel, D., \& Teoh, S. H. (1999). Issues in the Use of the Event Study Methodology: A Critical Analysis of Corporate Social Responsibility Studies. Organizational Research Methods, 2(4), 340-365. https://doi. org/10.1177/109442819924002.

Meyer, M. (2015). Positive Business: Doing Good and Doing Well. Business Ethics. A European Review, 24(S2), S175-S197. https://doi.org/10.1111/beer.12105.

Park, J. H., Park, H.-Y., \& Lee, H.-Y. (2018). The Effect of Social Ties between Outside and Inside Directors on the Association between Corporate Social Responsibility and Firm Value. Sustainability, 10, 3840. https://doi. org/10.3390/su10113840. 
Price, J. M., \& Sun, W. (2017). Doing Good and Doing Bad: The Impact of Corporate Social Responsibility and Irresponsibility on Firm Performance. Journal of Business Research, 80, 82-97. https://doi.org/10.1016/j. jbusres.2017.07.007.

Pimentel, L., Branca, A., \& Catalao-Lopes, M. (2016). International Comparisons of Corporate Social Responsibility. International Journal of Economics \& Management Sciences, 5(2). https://dx.doi.org/10.4172/2162-6359.1000327.

Servaes, H., \& Tamayo, A. (2013). The Impact of Corporate Social Responsibility on Firm Value: The Role of Customer Awareness. Management Science, 59, 1045-1061. https://doi.org/10.1287/mnsc.1120.1630.

Steurer, R. (2010). The Role of Governments in Corporate Social Responsibility: Characterising Public Policies on CSR in Europe. Policy Sciences, 43(1), 49-72. https://doi.org/10.1007/s11077-009-9084-4.

Steurer, R., Martinuzzi, A., \& Margula, S. (2012). Public Policies on CSR in Europe: Themes, Instruments, and Regional Differences. Corporate Social Responsibility and Environment Management, 19(4), 206-227. https://doi.org/10.1002/csr.264.

Turker, D. (2009). Measuring Corporate Social Responsibility: A Scale Development Study. Journal of Business Ethics, 85(4), 411-427. https://doi.org/10.1007/s10551-0089780-6.

Varadarajan, R., \& Kaul, R. (2017). Doing Well by Doing Good Innovations: Alleviation of Social Problems in Emerging Markets through Corporate Social Innovations. Journal of Business Research, 86, 225-233. https://doi. org/10.1016/j.jbusres.2017.03.017.

Wang, H., Tong, L., Takeuchi, R., \& George, G. (2016). Corporate Social Responsibility: An Overview and New Research Directions. Academy of Management Journal, 59, 534-544. https://dx.doi.org/10.5465/amj.2016.5001.
Yoo, D., \& Lee, J. (2018). The Effects of Corporate Social Responsibility (CSR) Fit and CSR Consistency on Company Evaluation: The Role of CSR Support. Sustainability, 10, 29-56. https://doi.org/10.3390/su10082956.

Jintao Lu

School of Economics and Management Taiyuan University of Science and Technology and Research Center for Corporate Social Responsibility

Taiyuan University of Science and Technology

P.R.China lut2002@163.com

Licheng Ren

School of Economics and Management Taiyuan University of Science and Technology and Research Center for Corporate Social Responsibility

Taiyuan University of Science and Technology

P.R.China rlc2000@sina.com

Wenfang Lin

School of Economics and Management Taiyuan University of Science and Technology

P.R.China lin1016a@163.com

Yifan He

School of Economics and Management Taiyuan University of Science and Technology

P.R.China he3865yf@163.com

Justas Streimikis

Lithuanian Institute of Agrarian Economics Division of Farms and Enterprises Economics Lithuania Justas.streimikis@gmail.com 


\title{
Abstract
}

\section{POLICIES TO PROMOTE CORPORATE SOCIAL RESPONSIBILITY (CSR) AND ASSESSMENT OF CSR IMPACTS}

\author{
Jintao Lu, Licheng Ren, Wenfang Lin, Yifan He, Justas Streimikis
}

The Corporate social responsibility (CSR) concept is linked to the company's responsibility for its impact on the society. The CSR is important for sustainability, competitiveness and innovation of the economy of each country and is tightly linked to the success in approaching Sustainable Development Goals (SDG) by the world countries. SDGs provide many benefits and opportunities for companies and in terms of risk management, increase the access to capital, improvement of stakeholders' relationships etc. The literature on CSR has shifted from analysing the questions on whether companies should engage in societal challenges to whether and how countries and people benefit from these interventions in addressing sustainable development challenges, such as poverty, education, health, energy and environment. The recent scientific discussion on the assessment of CSR impacts provides contradictory results and findings. Therefore, this paper aims to shed more light on this issue and provide clear policy recommendations based on the conducted analysis.

The paper analyses and compares the main policies that are aiming at the promotion of CSR, including reporting initiatives and requirements. The measures to assess the impact of CSR are discussed as well based on various reporting incentives that are guiding companies on how to assess and actually measure the effects of their activities by setting quantitative indicators. The dynamics of socially responsible companies and sustainability reporting initiatives are provided by indicating the effectiveness of the implemented policies and other initiatives to promote the CSR; however; the main emphasis of the paper is the impact of CSR on the societal challenges such as Sustainable Development Goals and integration of SDGs in the CSR assessment.

Key Words: Corporate social responsibility, sustainable development goals, policies to promote CSR, impacts of CSR.

JEL Classification: M14, Q56.

DOI: 10.15240/tul/001/2019-1-006 